Универзитет у Београду, Филозофрски фракултет, Београд

DOI 10.5937/kultura1755266Z УДК 730.071.1 Бакић В.

оригиналан научни рад

\title{
PA3MATPAHE MOГУTHOCTИ
}
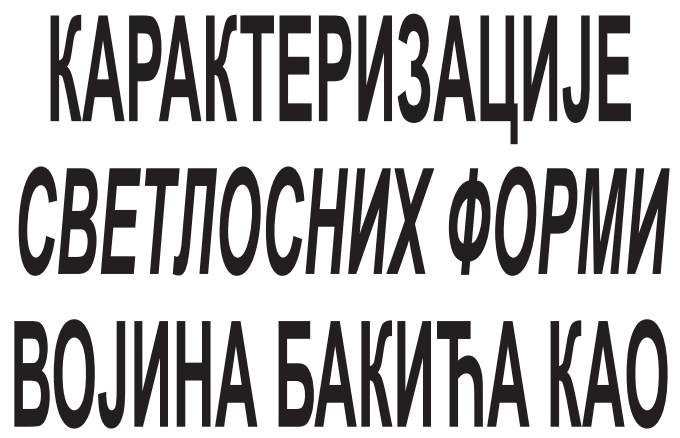

МИНИМАПАРТА

\begin{abstract}
Сажетак: У тексту ће бити речи о скулптурама Војина Бакића, пре свега о ниховим формама са аспекта формалне и контекстуалне анализе. Текст ће настојати да одговори на питање могу ли се пегове скулптуре Светлосне форме из 1963-64, посматрати као минимал арт или не и зашто, те стога који се аргументи у дефинисању и контекстуализаиији уметности минимала могу применити при карактеризаиији Бакићевих дела. Такође, поред формалне анализе, за разумевағе дела овог аутора потребно је посматрати контекст настанка дела, као и уметничке размене и утииаје. Настојаћу да изложим већ дате аргументе ликовних критичара/ки и историчара/ки уметности, као и да предложим своја разматрања о поменутој теми. Рад би, узевши претходну аргументаиију у обзир, указао на могућа тумачења у простору између датих категорија. Шира контекстуализаиија Бакићевих Светлосних форми и осврт на юима савремене и сродне уметничке феномене послужиће као смернице за даље истраживање у правиу могућег дефинисања минимал уметности на простору бивше Југославије.
\end{abstract}

Кључне речи: Војин Бакић, скулптура, минимал, модернизам, југословенска уметност 
Шездесете године у југословенској уметности обележава појава феномена нове фигурације или нове предметности, а како Денегри наводи, сасвим спорадично и по страни од водећих уметничких токова јављају се појединачни ставови у духу неконструктивизма и кинетичке уметности. ${ }^{1}$ У свом прегледу шездесетих година, он издваја уметнице/ке који стварају у духу постенформела, нове фигурације, нове геометрије и облика минималистичког сликарства. Присутни су у делима ових уметница/ка ставови модернизма о аутономији уметничког, односно самосталности ликовне стварности, као и изразита тежња ка редукционизму као крајњој инстанци ове самосталности. Ипак, тежња ка редукционизму није довољна да се одређено стваралаштво посматра као минимализам.

У југословенској уметности шездесетих и седамдесетих година у третирању скулпторалне форме јављају се две тенденције: једна ка редукцији и обнови чисте пластичке форме (минималистичке тендениије) и друга ка обнови фигурације и представљачке форме (поп-арт тенденциje). Минималистичке тенденције оличене су или у појави редуктивне апстрактне позномодернистичке уметности, или у неоавангардној појави неоконстуктивизма. Неоконструктивизам у случају југословенске уметности обухвата спектар уметничких форми од дела којим су аутори зашли у област редукције и минимализације градећи једноставне, таутолошке пластичке облике и ансамбле ${ }^{2}$ до кинетичких, луминокинетичких и (електро)техничких експеримената. Поприште промоције ове уметности било је у серији пет међународних изложби покрета Нове тенденције у Загребу између 1961. и 1973. године 3 . Нове тенденције су, међу осталим, промовисале радикалну обнову рационалистичке линије новог конструктивизма и његово преношење у тада актуелну проблематику кинетичке и програмиране уметности. ${ }^{4}$ Карактеристични су луминокинетички амбијенти Колемана Новака, механички произведемни цртежи Зорана Радовића и компјутерска гафика Петра Милојевића. ${ }^{5}$ Изложба

1 Denegri, J. (2013) Srpskaumetnost 1950-2000: Šezdesete, Beograd: Orion Art, str. 11.

2 Denegri, J. (1991) Vidiciminimalnog, Vidikiminimalnega - Minimalizem v slovenskiumetnosti 1968-1980. Moderna galerija Ljubljana, kolovoz - rujan 1990, Život umjetnosti br. 48/49, Zagreb: Institut za povijestumjetnosti u Zagrebu, str. 114.

3 Denegri, J. (2013) нав. дело, стр. 12.

4 Župan, I. (2013) Svjetlosni oblici Vojina Bakića, ArsAdriatica 3, Zadar: Sveučilište u Zadru, str. 214.

5 Šuvaković, M. (2010) Istorija umetnosti u Srbiji XX veka: Radikalne umetničke prakse, Beograd: Orion art, str. 257. 
интернационалне неоконструктивистичке уметности - Конструктивна уметност - Елементи и принципи одржана је у Музеју савремене уметности у Београду 1969. године. У секцији Нова тенениија 3. београдског тријенала излагали су, поред загребачких тенденцијаша, и југославенски/е уметници/це који нису у вези са покретом Нове тенденције. ${ }^{6}$ Међу њима су били уметници/це оријентисани ка радикалној апстракцији - Војин Бакић, Ана Бешлић, Мира Бртка, Борис Цикаловски, Милена Чубрековић, Јурај Добровић, Еуген Фелер, Младен Галић, Јулије Книфер, Иван Кожарић и др. Хибридно повезивање уметника различитих опредељења под именом Нове тенденције довело је до полемика и расправа о статусу апстракције. ${ }^{7}$ На проблемским секцијама 4. београдског тријенала југословенске уметности Објекти, Прије и око нове тендениије, Кониептуална уметност и Конкретна визуелна поезија, предочене су нове појаве и тенденције неоавангардне уметности. ${ }^{8}$

Ивица Жупан наводи да се „унутар кинетичке продукције тијеком 1960-их оствариване у хрватској умјетности разликују најмање три постулације у дефинирању сустава односа објект - простор-свјетло-покрет: Прва је категорија слободне аналитичности утемељене на интуитивну осјећају реда (Бакић, Мирослав Шутеј); друга је категорија објективне аналитичности утемељене на провјери нумеричког програма (Вјенцеслав Рицхтер, Иван Пицељ, Јурај Добровић); трећа је категорија техничке аналитичности засноване на провјери сустава механизама темељених на погонском дјеловању електроенергије (Александар Срнец)." Н Нису све ове кинетичке тенденције неоконструктивизма имале одлике уметности минимала, мада се у свакој од њих могу наћи примери уметности која има тенденције ка редукованим и апстрактним формама, чистоти израза, изражајности кроз материјал, модуларности облика и геометризацији форми.

Денегри истиче да је на питање шта се подразумева под појмом минималног у југословенском уметничком простору настојао одговорити Маријан Сусовски на изложби у Галерији сувремене умјетности у Загребу 1983, утврдивши заступљеност знатног броја аутора који су се у току шездесетих и седамдесетих година служили редуктивним, што не

6 Šuvaković, М. нав. дело, стр. 257.

7 Исто.

8 Исто.

9 Župan, нав. дело, стр. 211. 
значи и изразито минималним и минималистичким формама у изворном значењу тога термина. ${ }^{10}$

Изложба Видики минималнега, одржана у Модерној галерији у Љубљани, сасвим је јасно показала да ни на словенској уметничкој сцени минимализам није јединствена и једнократна појава, него да се јавља у неколико наврата, у више таласа, садржавајући низ језичких врста и подврста, а свима је заједничко разматрање неких темељних онтолошких питања уметности и уметничког дела као аутономних духовних ентитета. ${ }^{11}$

Када се говори о минималистичким тенденцијама југословенске уметности треба истаћи да ту није реч о минималном/ минимализму у радикалним позицијама какве се налазе у пракси и у теорији Роберта Мориса (Robert Morris) и Донада Џада (Donald Judd), него пре о низу различитих редуктивних захвата на које би се могла применити ознака Марселина Плејнеа (Marcelin Pleunet) о минималним облицима као аутономним ентитетима утемељеним на структуралним међузависностима. ${ }^{12}$

У том контексту Денегри поставља логично питање мора/ може ли се појава минимализма на југословенској уметничкој сцени видети као одјек последица или деривација америчког феномена минимал арта. Он истиче да су на настанак ове праксе редукционизма утицали поред америчких и европски извори, као и они локални - попут загребачке геометријске апстракције групе EXAT-51, што је доводило до прожимања различитих уметничких пракси и стварања аутентичних уметничких појава. Стога је, Денегри закључује, немогуће дефинисати редукционизам у југословенској уметности као минимал арт. ${ }^{13}$

Он порекло ових појава такође види у утицају климе касног модернизма и интернационализацији локалних уметничких збивања:

„Посредни или непосредни потицаји могу тражити у неким збивањима у саставу венецијанског Бијенала 1964. и 1966, посебно у експанзивним америчким наступима у којима се тих година промовирају Морис Луис (Morris Louis), Ноланд (Kenneth Noland), Стела (Frank Stella), Keли (Ellsworth Kelly)и Олицки (Jules Olitski) на апстрактном, односно Роберт Раушенберг (Robert Rauschenberg),

10 Denegri, J. (1991) нав. дело, стр. 114.

11 Исто.

12 Исто.

13 Исто. 
Џаспер Џоунс(Jasper Johns), Олденбург (Claes Oldenburg), Дајн (Jim Dine), Лихтенштајн (Roy Lichtenstein) и Џон Чемберерлејн (John Chamberlain на предметном и представљачком крилу умјетности седмог десетљећа.”14

Скулптура Војина Бакића не припада неокоструктивистичким и неоавангардним тенденцијама и експериментима. Његова уметност се креће од раног модернизма (кубистичког утицаја видљивог у скулптури Бик) ка позномодернистичкој редуктивној апстракцији (видљивој у скулптурама шездесетих). Ни Денегри ни Шуваковић не сврставају Бакића међу уметнике који се баве неоконструктивистичким тежњама и проблемима. Они његова дела виде као радикалну апстракцију и као уметника високог модернизма.

Ипак, између Бакићевих скулптура насталих шездесетих Светлосне форме из 1963-64. године и скулптура појединих америчких уметника конструктивистичких тенденција који су стварали педесетих и шездесетих има сличности у ликовном поступку. Један од таквих уметника је Дејвид Смит (David Smith), кога карактеришу и као скулптора апстрактног експресионизма. Његова дела из серије Cubi настала између 1961. и 1965. године показују изразито модернистичка схватања скулптуре. Форме су апстрактне, геометризоване и сведене, али уметник задржава композицијску сложеност и ефекат који подразумева емотивну реакцију. Исте одлике имају Бакићеве Светлосне форме/Свјетлосни облици из 1963. и 1964. године. Уметник ствара структуре од модуларних јединица различитих величина, али готово истих облика користећи нове материјале, попут нерђајућег челика. Иако се коришћење модуларних јединица, као и нових материјала запажа као есенцијално у минимал арту, Бакићеве Светлосне форме немају карактер минимала, јер ови истоветни поступци нису коришћени у истоветну сврху као у минимализму. Док је циљ уметности минимала да редукује сензацију, да лиши дело карактера, емотивног и субјективног утиска и да прокламује хладну и ригидну структуралност као циљ уметничког израза, дела Војина Бакића задржавају намеру да оставе, како ликовни тако и субјективни (емотивни) утисак на посматрачицу/а. Управо су то уметници минимал-а (Dan Flavin, Carl Andre, Sol Le Witt) замерали скулпторима конструкционизма педесетих. Колико год да је дело Дејвида Смита апстрактно, за њих је било превише фигурално. ${ }^{15}$ Оно што остаје као баштина модернистичке скулптуре код

14 Исто, стр. 115.

15 Foster, H. and Krauss, R. (2012) Art since 1900, London: Thames \& Hudson, p. 472. 
Бакића и Смита јесу традиције кубистичког редукционизма, естетизација форме и сам третман дела као још увек скулптуре, а не као инсталације или објекта.

Такође, обојица у својим радовима задржавају модернистичке односе аутор-дело и дело-публика. Док је минимал арт прокламовао смрт аутора и отклон од субјективног у сваком смислу (и изражавања аутора и учитавања публике), дела Бакића и Смита и даље поседују експресивна својства апстрактне уметности педесетих. Начин на који ове форме рефлектују светлост, обликују прстор и мењају перцепцију простора код посматрача говори у прилог томе да је у питању ипак задржавање одређеног вида илузионизма који је у уметности минимала негиран. Циљ да се одређени визуелни ефекат и сензација пренесу посматрачици/чу није никада био циљ минимала, објекти и њихове форме у уметности минимала су саме себи циљ - односи форми међсобно и њихов однос са простором су фокус пре него публика и њена перцепција. Посматрајући скулптуре циклуса Светлосне форме, уочава се да свака посматрачица и сваки посматрач добија сопствену импресију, да је посматрање персонализован процес и да је у том смислу далеко од хладних објеката минимал арта који теже јединственој сензацији односа просторног и предметног. Код Бакића је однос особе која посматра судионички, док је у минималу, узевши Фрајдову (Fried) теорију у обзир, театарски ${ }^{16}$. Пред публиком се одвија предмет и простор, она не суделује у настанку значења, она је само приматељка сензација која је униформна. Бакић тиме пре наставља традицију модерниста који су од самог почетка модернизма желели да успоставе судеонички насупрот театарском односу.

Начин на који Војин Бакић користи материјале, иако су то често исти материјали којима се служе уметнице/и минимала, и даље је ликован. Уметници/уметнице минимала су покушавали да експресивност материјала сведу на минимум као и његову ликовност, а да у први и једини план истакну физичко присуство, просторност и кореспонденцију предмета/његовог материјала са околином. Употреба материјала са својствима огледала је у уметности минимала служила да још више истакне модуларност, репетативност и баналност форме, док је код Бакића, као и Смита, служила да, рефлектујући сопствене делове, амбијент и публику створи визуелну игру која се одвија на површини скулптуре мењајући њен изглед, карактер, па и значење. Површине са

16 Fried, M. (1967) Art and Objecthood: http://atc.berkeley.edu/201/readings/ FriedObjcthd.pdf(Преузето 1. авг 2017, 11:35). 
својствима (или делимичним својствима) огледала доприносила су у њиховим делима динамици и ликовном диверзитету визуелног утиска. У уметности минимала динамика није пожељна, управо супротно - пожељна је статика форме и визуелног утиска, а стога и статика значења (односно одсуства могућих значења). Диверзитет такође није пожељан у минимализму, мада су уметници или уметнице минимала често стварали дела која су ликовно занимљива упркос њиховој намери да се од тога ограде. За уметнике или уметнице минимала овакве скулптуре, попут Смитових, су превише пикторалне, донекле и илустративне и наративне. ${ }^{17}$

Војин Бакић обликујући Светлосне форме, према речима Жупана: „Модулирањем дискова - истоврсних зрцалних јединица - стварајући ефектне структуре и рабећи и нов градбени материјал - нехрђајући челик и инокс, материјал који, барем не у нашој средини, тада нема неку повијест нити језичну прошлост - кипар у Свјетлосним облицима истодобно слиједи начела геометријске апстракције и оптичких истраживања." 18 Упркос оптичким елементима и визуелној игри коју (лумино)кинтетика проузрокује, Бакићеве Светлосне форме нису подведене под оптичку, кинтеичку и луминокинетичку уметност - управо због одсуства техничких механизама и динамике која је програмски или машински произведена. Бакићу је у фокусу ликовни ефекат који производи метеријал. И мада је овај материјал индустријски, само дело је далеко од тога да буде посматрано као нека врста дела-машине.

Жупан правилно примећује да је Бакићева композицијска метода импровизирајућа и да настаје на темељу поступка који је искључиво мануалне нарави и не покорава се оквирима геометријских прорачуна: „Објекти, дакле, нису остварени по нацртима прецизних аналитичких студија, обвезатно утемељеним на нумерички регулираним правилностима и пропозицијама, нити се њихов аутор - визуално и обликовно - служи бројком." ${ }^{19}$ Стога овде не може бити говора о серијској производњи какву су на уму имали/е уметници/ це минимал арта. У фокусу аутора остаје композиција делова рада у визуелну целину која није статична, програмски структуирана и монолитна.

Задржавши ликовност као вредност, и композицију која није генеричка као својство дела, уметници позног модернизма не преиспитују вредност традиционалних ликовних

17 Foster, H. and Krauss, R. (2012) нав. дело, стр. 473.

18 Župan, нав. дело, стр. 216.

19 Исто. 
елемената као што то чине уметници минимала, већ откривају нове могућности њихове употребе. Наведена својства говоре у прилог томе да се у случају Бакића (и Смита) редукционизам форме није огледао у минималистичкој тежњи ка редукционизму значења, већ у позномодернистичкој тежњи за чистотом апстрактне геометријске форме.

Такође, значењске евокације говоре у прилог разликама Бакићевих скулптура и примарних структура минимализма. Роберт Морис јасно указује на то чему су све уметници минимала рекли не: не трансценденталним и спиритуалним вредностима, не херојским, стрепљивим изборима, историјском наративу, вредном артефакту, интелигентној структури, занимљивом визуелном искуству. ${ }^{20}$ Бакић у својим делима задржава структуру, понекад наратив, па чак и херојско и спиритуално, али посебно задржава, и чини се вреднује, занимљиво визуелно искуство. Он, за разлику од уметника минимализма, ниједног тренутка не показује претензије да његов редукционизам постане монотон, једноличан и хладан. Бакић не претендује на одсуство значења, контекста и ефекта.

У делу Војина Бакића се чак ни у периодима када су форме трпеле највећи степен редукције и стилизације, није десила деперсонализација у уметничком поступку, карактеристична за уметнике минимала. У његовој уметности нема те врсте фабричке продукције дела и потпуног изостанка ауторовог отиска који уклања са дела ауру уметничког објекта. Бакићеве скулптуре су и даље обликоване тако да у њима опстаје идеја уметника као креативног ствараоца дела. Он задржава категорију стила и аутентичности уметничког израза, што је такође наслеђе модернизма - посебно оног касног модернизма америчке и европске уметности педесетих у коме је статус уметника/це, као стваралачке индивидуе која се кроз уметност изражава, био од посебне важности.

Оно пак што повезује позне модернисте попут Бакића и минималисте је што деле идеју о аутономији уметности. Не само о аутономији ликовне реалности, већ и о аутономији од употребне вредности. Док је конструктивизам као историјска авангарда покушао да споји уметност и рад, употребу и инжињеринг, минимал прокламује бескорисност уметничког објекта, односно недостатак његове употребне вредности - као што је Сол Ле Вит рекао: „Art is not utilitarian”. ${ }^{21}$ Ипак, категорија самосталности уметничког дела и његове неупотребљивости у практичном смислу карактеристична је

20 Foster, H. and Krauss, R. (2012) нав. дело, стр. 462.

21 Исто, стр. 465. 
и за модернистичку мисао, с тим што је уметност минимала ову тенденцију довела до крајњих граница.

Такође, идеја коју југословенски редукционизам (стога Бакићева уметност) и неоконструктивизам деле са минимал артом је идеја о трансгресији медијума са слике и скулптуре на објекте. На изложби Објетки и боја'968 у Галерији Центар у Загребу 1968, као и у секцији Објекти у саставу Тријенала МСУБ 1970. године појавиле су се тенденције спајања пластичких и сликарских особина форме. ${ }^{22}$ Ипак, не би се могло поуздано тврдити да су Бакићеве скулптуре овај тип скулптуре-објекта. Иако оне понекад садрже ликовност и пикторалност сликарске композиције (када су у питању Светлосне форме или Разрезане површине ово долази посебно до изражаја) не може се тврдити да прелазе границу у којима скулптуре постају објекти. Сличну проблематику уочавамо и код уметника Томислава Каузларића, који је, како Денегри наводи, током друге половине шездесетих био једини заступник идеје скулптуре-објекта. ${ }^{23}$ Преломна је била самостална изложба Каузларића у Галерији Коларчевог универзитета 1967, управо којом овај аутор у подручје српске уметности уноси тада нови пластички род тада уведен и прихваћен под називом скулптура-објект. ${ }^{24}$ Док Каузларићева дефинитивно јесте скулптура-објект будући често peферентна на ready-made, за Бакићеву скулптуру која овај елемент не садржи не може се тврдити да одговара појму скулптура-објекат. Каузларићева скулптура-објекат остаје и даље наративна и асоцијативна, док се Бакић у истом период позних шездесетих и седамдесетих ослобађа директне асоцијативности и наратива. У Бакићевим формама не постоји миметичности и референцијалност на реалност. Облици и материјали су артифицијелни, називи универзални а значење композиција је отворено за интерпретације. Такође, у самим називима наставља модернистичку традицију да апстрактне форме назива једнако апстрактним називима Светлосне форме или Разрезане површине.

Однос делова и целине јако је битан за уметност минимализма. Концепт гешталта - међузависности и условљености целине деловима и обрнуто је за уметност минимализма значајан посебно ако се у обзир узме начин компоновања, структурна устројеност дела, једнообразност делова и униформност целине. Код Војина Бакића је посебно виљдива ова међузависност, јер он, (као и Смит) не одустаје од

22 Denegri, J. (2013) нав. дело, стр. 295.

23 Исто, стр. 275.

24 Исто, стр. 276. 
одређеног степена формалне сложености гешталта. И док оба аутора имају тенденденцију да понављају форме, ове форме нису идентичне, као ни њихови међуодноси. Коцка или круг нису понављани серијално као да су индустријски произведени, они варирају у димензијама и композицји. На тај начин аутори задржавају приступ уметника модернизма - аутор је творац форме и значења, и форма носи обележје свог ствараоца. Индивидуално није уступило место генеричком као у уметности минимализма. Иако игра велику улогу у посматрању и тумачењу Бакићеве скулптуре, гешталт није једноставан и униформан као гешталт у скулптури уметника минимала.

Тешко је дефинисати шта је минимал арт, а шта није, што онемогућава да се овај феномен посматра као јединствен покрет стилски и идејно. Џад говори о специфичним објектима пре као тенденцији која има широк спектар испољавања у различитим уметничким медијумима и формама него као покрету. Он говорећи о овој новој тенденцији наводи читав низ различитих уметничких појава које су и по форми и по садржају врло разнолике, а често и потпуно различите. Нове тродимензионалне форме не чине покрет, школу или стил. Заједнички чиниоци су превише општи и премало тога имају сличног да би се дефинисали као покрет. Разлике су веће него сличности. Сличности се уочавају међу одабраним делима; али оне нису принципи или ограничавајућа правила. ${ }^{25}$ Он побраја уметнике разних покрета, од новог реализма у Француској (попут Клајна (Yves Klein) и Армана (Arman), преко британских уметника (Филипа Кинга (Phillip King)) до уметника Западне обале (Лери Бел (Larry Bell), Киенхолз (Edward Kienholz)) и њујоршких уметника/ца (Роналд Блејден (Ronald Bladen), Роберт Морис, Кусама (Yayoi Kusama), Сегал (George Segal), Флавин (Dan Flavin), Олденбург). На први поглед се не може уочити сличност између дела која стварају ови уметници/це, али оно чиме их је Џад повезао је управо тенденција да се изгубе границе медија уметничког израза, као и да се тежи тродимензионалности форме, односно њеној објектификацији. Управо због ширине појмова минима арта, примарних структура, специфичних објеката, тешко је одредити да ли нека уметност јесте или није минимализам.

Скулптуре циклуса Светлосне форме Војина Бакића, чини се, ове опште (најопштије) услове да се назове Џадовим објектом испуњава, међутим њен циљ није била трансгресија

25 Judd, D. (1965) Specific Objects: http://atc.berkeley.edu/201/readings/juddso.pdf (Preuzeto: 1. avgusta 2017, 11:30). 
медијума скулптуре у објекат, већ само проширење појма скулптуре ка новим апстрактним и динамичним формама. Минимал није само формални језик геометрије, редукције и апстракције, већ је и идеологија којом су уметници/це исказали/е своје ставове о уметности. Бакић колико је познато није делио ставове америчких уметника шездесетих година, и из његовог развојног пута се не уочава да је свесно тежио уметности минимализма. Но, како минимал није јединствена идеологија или покрет, не може се за одређено дело рећи припадали или не припада минималу, може се само говорити у којој мери кореспондира са идејама и формама ове уметности. Бакићева скулптура садржи одлике редукционизма, она тежи геометризацији, сведености форме и апстракцији у изразу, но и даље, она не тежи да све ове тенденције доведе до крајњих тачки у којима се губи ауторски отисак, експресивност форме и композициона сложеност. Може се, дакле, закључити да скулптура Војина Бакића не припада ни неоавангардним тенденцијама неоконструктивизма, ни уметности минимала као покретима, иако понекад дели њихове формалне изразе или чак садржи одлике обе, условно речено, тенденције.

\section{ЛИТЕРАТУРА:}

Denegri, J. (2013) Srpska umetnost 1950-2000: Šezdesete, Beograd: Orion Art.

Denegri, J. (2013) Srpska umetnost 1950-2000: Sedamdesete, Beograd: Orion Art.

Denegri, J. (1991) Vidiciminimalnog, Vidikiminimalnega - Minimalizem v slovenskiumetnosti 1968.-1980, Moderna galerija Ljubljana, kolovoz - rujan 1990, Život umjetnosti br. 48/49, Zagreb: Institut za povijestumjetnosti u Zagrebu.

Župan, I. (2013) Svjetlosni obliciVojina Bakića,Ars Adriatica 3/2013, Zadar: Sveučilište u Zadru.

Šuvaković, M. (2010) Istorija umetnosti u Srbiji XX veka: Radikalne umetničke prakse, Beograd: Orion art.

Foster, H. and Krauss, R. (2012) Art since 1900, London: Thames \& Hudson.

\section{Интернет извори:}

Fried, M. (1967) Artand Objecthood: http://atc.berkeley.edu/201/readings/FriedObjcthd.pdf (Preuzeto 1. avgusta 2017, 11:35)

http://www.ipu.hr/content/zivot-umjetnosti/ZU_48-49-1991_114-

117_Denegri.pdf (Preuzeto 1. Avg 2017, 12:00)

Judd, D. (1965) Specific Objects: http://atc.berkeley.edu/201/readings/ judd-so.pdf (Preuzeto 1. avgusta 2017, 11:30) 
Morris, R. (1966-67) Notes on Sculpture: http://arts.berkeley.edu/wpcontent/uploads/2016/01/robert-morris-notes.pdf (Preuzeto 1.

avgusta $2017,11: 32$ )

Ana Simona Zelenović

University of Belgrade, Faculty of Philosophy, Belgrade

\title{
RETHINKING THE POSSIBILITY OF CHARACTERIZING LIGHT FORMS OF VOJIN BAKIĆ AS MINIMAL ART
}

\begin{abstract}
This paper focuses on sculptures of Vojin Bakić and on their forms from the perspective of formal and contextual analysis. The paper will try to answer the question if his sculptures 'Light forms' (19631964) can be considered minimal art or not and why, and thus which arguments in defying and contextualizing art as minimal can be used to characterize his artworks. Also, for understanding these artworks it is necessary to take into consideration the context of their occurrence as well as the influence made by other movements and artists. I will provide arguments of other art historians but also my own reflections about this subject. The paper will try to place Bakić's 'Light forms' in already given categories. The wider contextualization of his 'Light forms' and rethinking its characteristics as minimal art can serve as directions for further research and possible definitions of the art of the 60 s in Yugoslavia.
\end{abstract}

Key words: Vojin Bakić, minimal art, sculpture, modernism, art in Yugoslavia 